\title{
Alteration due to Prolonged Food Deprivation in Protein Content of Muscles and Brain of Clarias batrachus
}

\author{
Nayan K. Prasad \\ Department of Zoology, R.R.M. Campus, Tribhuvan University, Janakpur, Nepal \\ e-mail: nayankumar.prasad@gmail.com
}

\begin{abstract}
The present paper deals with the impact of starvation on fish which has a great ability to adapt in the prolonged starvation condition. In the present investigation, the impact of starvation on protein contents of muscle and brain tissues has been observed in both the sexes of Clarias batrachus. The level of protein content was relatively higher in females than in males. The brain showed higher value of protein in normal condition $(138 \mathrm{mg} / \mathrm{g}$ in male and $153 \mathrm{mg} / \mathrm{g}$ in female) in comparison to the muscles $(132 \mathrm{mg} / \mathrm{g}$ in male and $140 \mathrm{mg} / \mathrm{g}$ in female). During prolonged food deprivation, the gradual decrease in protein level has been noticed in all types of tissues which can be related to blocking of RNA synthesis, enhanced gluconeogenesis and increased rate of transamination and deamination. The maximum depletion has been observed in muscles ( $48 \%$ in male and $46 \%$ in female) and the least depletion in the brain (3\% in male and 6\% in female) after 40 days of starvation.
\end{abstract}

Key words: brain, Clarias, muscles, protein, starvation.

\section{Introduction}

Starvation, semi-starvation and malnutrition in living beings stand in the front lines of the outstanding global problems. The situation is pitiable in the underdeveloped nations as well as developing countries. Recent literature survey by the Food and Agricultural Organization of the United Nations (2011) predicts a gloomy and hopeless condition of the food situation in the $21^{\text {st }}$ century. Since the emergence of life on the earth, starvation has been a continuing struggle of living beings. Organisms facing the starvation fight against it at the cost of their own body reserves.

The present study aims to know the facts and causes of starvation and their consequent impacts on animals. A number of similar studies have been carried out, but most of the works have been confined to mammalian fauna. In Nepal, very little works have been done to study the starvation-induced effects in fishes. So, it is pertinent to see and reveal the effect of starvation on fish as there is a unique feature of fish to withstand prolonged starvation through physiological and biochemical changes (Mustafa 1983).
Most species of fish experienced starvation during certain period of a year largely due to the environmental conditions, which affect the physiological status and biochemical constituents of fish (Rajyasree \& Naidui 1989, Mukhopadhyaya et al. 1991, Tripathi \& Verma 2003). the present study, therefore, is designed to know the level of protein content of muscular and nervous tissues of Clarias batrachus during prolonged period of starvation of 40 days starting from 0 days to 40 days by estimating protein constituents at an interval of 10 days.

\section{Methodology}

For the present investigation, healthy live fish were collected from a local fish pond with the help of fishermen. The fish were brought to the laboratory in large earthen pots covered with mosquito net. They were identified according to Shrestha (1981) and were treated with $0.1 \% \mathrm{KMnO}_{4}$ solution for five minutes to get rid of any dermal infection. Healthy fish of an average length $(18.8 \mathrm{~cm})$ and weight $(34.4 \mathrm{~g})$ were transferred one by one with the help of small hand net to a large glass aquarium of about 110 litres capacity measuring about $75 \mathrm{~cm} \times 30 \mathrm{~cm} \times 45 \mathrm{~cm}$ in size. They 
were allowed to acclimatize under laboratory condition for 20 days. During this period, the fish were fed twice daily with commercial fish food to avoid their starvation. Twenty four hours before starting the experiment, the food was stopped to clear off the alimentary canal. The study was carried out from May 2009 to June 2013.

Biochemical estimations were made by taking the samples from each sex of acclimatized and well fed fish and the values obtained were taken as normal value for C. batrachus. A control group was kept in tap water. The remaining fishes were divided into four batches - A, B, C and D keeping 10 fishes each (5 males and 5 females). The fishes of batch A were kept without food at room temperature for 10 days, that of batch B for 20 days, C for 30 days and D for 40 days.

Starting from 0 day up to 40 days, the fish were dissected at an interval of 10 days. Their muscles and brains were removed and placed immediately in the ice-cold fish saline for different biochemical studies. Before transferring the muscles and the brains into saline, they were properly cleaned by removing other attached tissues. The muscles were removed from the lateral side with the help of scalpel and scissors and cleaned of the nerves. Before use, the tissues were blotted with filter papers.
The total protein contents of muscles and brains were determined by adopting the method of Sutherland et al. (1949), using Folin Ciocalteau reagent. The weighted quantity of the muscles and the brains were homogenized in tissue homogenizer. The homogenates were diluted 200 times in distilled water. $0.5 \mathrm{ml}$ samples of diluted homogenates were taken in test tubes in duplicate and $2.5 \mathrm{ml}$ of the protein reagent (Layne, 1957) were added to each and mixed well. The mixture was allowed to stand for $40 \mathrm{~min}$. at room temperature. After this, $0.25 \mathrm{ml}$ of Folin Ciocalteau reagent was added to each test tube. The tubes were shaken and allowed to stand for another $15 \mathrm{~min}$. at room temperature for colour development. The optical density of the solution was read in the colorimeter exactly after 15 minutes. Parallel blanks having $0.25 \mathrm{ml}$ of distilled water instead of homogenates were prepared each time. The concentration of protein (mg/g weight) was determined from a standard curve.

\section{Results and Discussion}

In present study, the level of protein content was found relatively higher in females than in males. The gradual decline in the protein content was observed in all the types of tissues in question. The maximum depletion was in muscles and least in the brain (Table 1). The starvation for 10 days in present study revealed a minimum depletion suggesting protein as the last biochemical constituent to be depleted during starvation.

Table 1. Protein content of muscles and brain (mg/g wet tissue) of Clarias batrachus

\begin{tabular}{|c|c|c|c|c|c|c|}
\hline \multirow{2}{*}{ Organ } & \multirow{2}{*}{ Sex } & \multirow{2}{*}{ Control } & \multicolumn{4}{|c|}{ Starvation Period } \\
\hline & & & 10 days & 20 days & 30 days & 40 days \\
\hline \multirow{4}{*}{ Muscles } & & 132.61 & $123.82 * *$ & $102.30 * *$ & $86.30^{* *}$ & 68.64 \\
\hline & Male & \pm 0.49 & \pm 0.76 & \pm 0.42 & \pm 0.45 & \pm 0.65 \\
\hline & & 140.33 & $131.75^{* *}$ & $109.03 * *$ & $96.37 * *$ & $74.58 * *$ \\
\hline & Female & \pm 0.57 & \pm 0.78 & \pm 0.55 & \pm 0.34 & \pm 0.84 \\
\hline \multirow{4}{*}{ Brain } & & 138.27 & 138.50 & 137.60 & 137.58 & 133.99 \\
\hline & Male & \pm 1.59 & \pm 1.51 & \pm 1.67 & \pm 0.88 & \pm 1.43 \\
\hline & & 153.45 & 152.08 & 151.10 & 149.00 & 144.15 \\
\hline & Female & \pm 0.92 & \pm 0.80 & \pm 0.85 & \pm 0.69 & \pm 0.94 \\
\hline
\end{tabular}

Values are the mean of eight samples of both male and female $( \pm$ SE) fishes ** Significant

Protein is the fundamental component of protoplasm and consequently it determines both the forms and functions of all living system. Loss or mobilization of the proteins during stress varies widely among different organisms and tissues (Addis et al., 1936).

Drilhon (1954) observed that the impact of starvation on protein content was felt sooner in active fish than sluggish one. Cordier et al. (1957) reported considerable reduction in the concentration of serum protein in Scyllium canicula after starvation for 15 days. Fujiya (1961), Sorvachev (1957), Dessauer and Fox (1956) reported gradual drop in plasma protein of various starving animals. Thomas and McCrimmon (1964) observed changing electrophoretic pattern in Petromyzon marinus on starvation. 
Turning now to the solid tissues of the body, it was found that in common with mammals, fish broke contractile proteins more rapidly and readily than connective tissue protein during starvation (Love 1970). The principal connective tissue protein, collagen has a stable molecule and since it is mobilized very little, the relative quantity increases during starvation (Fisher \&- Griminger 1963).

Addis et al. (1936) found that in rats, fasted for 7 days, several tissues contributed to the total protein loss in the following proportion: muscles and skin $62 \%$, liver $16 \%$, alimentary canal, spleen and pancreas $14 \%$, blood $6 \%$, kidney $1 \%$, heart $0.5 \%$ and remaining organs $0.5 \%$. Sobel et al. (1967) observed mobilization of collagen from the skin of mice.

In the present investigation, the gradual decrease has been noticed in muscles and brains of both the sexes of C. batrachus. However, the maximum depletion has been observed in the muscles and least in the brain. The starvation for 10 days in both the organs showed minimum depletion suggesting protein as last biochemical constituent to be depleted.

The protein content of $C$. batrachusin the muscles and brains after specific days $(0,10,20,30 \& 40)$ of starvation has been depicted in Figures 1 and 2 .

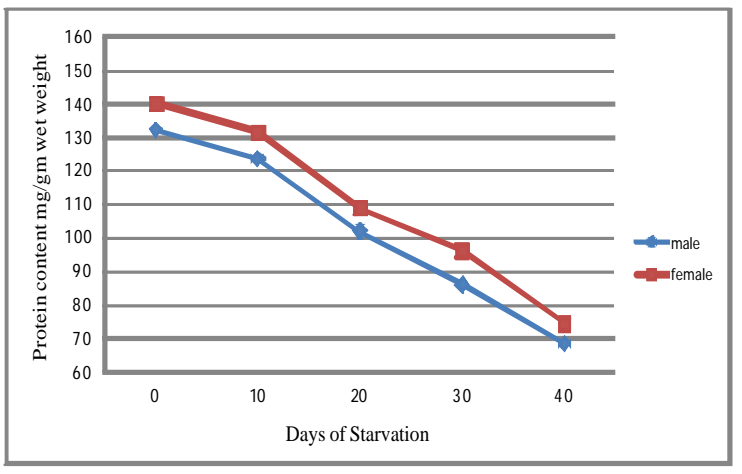

Fig. 1. Effect of starvation on protein content of the muscles in C. batrachus

\section{Acknowledgements}

The author renders his heartfelt gratitude to Prof. Dr. R. P. Sinha and Prof. Dr. A. K. Verma, Department of Zoology, C. M. Science College, LNMU, Darbhanga, for their generous and constant guidance as well as for providing lab facilities for this research work.
Among the solid tissues investigation, the brain showed the highest value of protein in normal condition (about $153 \mathrm{mg} / \mathrm{g}$ ) with a minimum depletion of about $3 \%$ even in 40 days starved fish. However, the muscles showed least value of protein in the normal condition (about $132 \mathrm{mg} / \mathrm{g}$ ) with greatest depletion of about $48 \%$ in 40 days starved fish.

Starvation causes slow proteolysis in brain in comparison to the muscles. The muscular tissues showed significant drop in protein content both in male and female individuals during starvation but there has been non-significant depletion in protein content of brain tissues.

The maximum decline in muscles can be related to the blocking of RNA synthesis due to starvation. At the same time, the exhaustion of carbohydrates and fats in initial phase of starvation reflects the least protein decline whereas later phase of starvation involved much protein depletion in the absence of other food deposits. Further, the protein depletion may be associated with impaired carbohydrate metabolism which enhances protein transamination and deamination to meet the energy demand in the condition of acute starvation as noticed in all types of tissues in consideration.

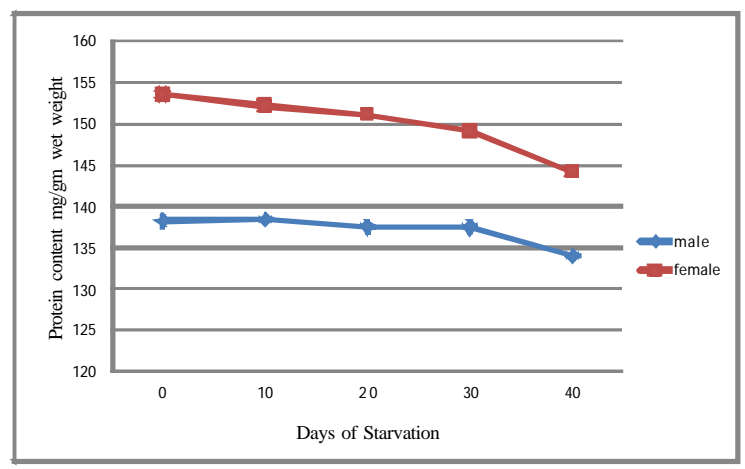

Fig. 2. Effect of starvation on protein content of the brains in C. batrachus

\section{References}

Addis, T., L.J. Poo \& W. Lew. 1936. The quantities of protein lost by various organs and tissues of the body during a fast. J. Biol. Chem. 115: 111-116.

Cordier, D., R. Bernoud and A.M. Bredon. 1957. Study on the blood protein of dogfish (Scyllium canicula. L.); 
Nepal Journal of Science and Technology Vol. 16, No.1 (2015) 95-98

Influence of starvation. C. R. Seanc. Soc. Biol. 151: 1912-1915.

Dessauer, H.C. and W. Fox. 1956. Characteristic electrophoretic patterns of plasma proteins of orders of amphibia and reptilia. Science, N. Y. 124: 225-226.

Drilhon, A. 1951. Biological study of several fish blood serum proteins. C. R. Seances. Soc. Biol. 148: 12151220.

FAO. 2011. In the 21st century: Ensuring food security in a changing world. Food and Agriculture Organization of United Nations. Rome, Italy.

Fisher, H. and P. Griminger. 1963. Ageing and food restrictions: Changes in body composition and hydroxyproline content of selected tissue. J. Nutr. 80: 350-354.

Fujiya, M. 1961. Use of electrophoretic serum separation in fish studies. J. wet. Pollut. Control. Fed. 33: 250257.

Layne, E. 1957. Spectrophotometric and turbidimetric methods for measuring proteins. In: Methods in Enzymology. Academic press, New York. London. 3: 447-454.

Love, R.M. 1970. The chemical biology of fish. U.S. Edition, Academic Press. London, N.Y., Pp. 222-256.

Mukhopadhyay, P.K., S.N. Mohanty, K.M. Das, S. Sarkar and B.C. Batra. 1991. Growth and changes in carcass composition in young of Labeo rohita and Cirrhinus mrigala during feeding and starvation. In: Fish Nutrition Research in Asia. Proc. of the 4th Asian Fish, Spec. Publ. Asian Fish Soc. 5: 87-91.

Mustafa, S. 1983. Changes in biochemical composition in starving catfish Heteropneustes fossilis. Japanese Journal of Ichthyology 29: 4.

Rajyasree, M. and K.R.P Naidu. 1989. Starvation induced changes in biochemical aspects of hepatic tissue of fish, Labeo rohita. Indian J. Fish. 36: 339-341.

Shrestha, J. 1981. Fishes of Nepal. First ed., Curriculum Development Centre, Tribhuvan University, Kathmandu.

Sobel, H., M.J. Hewlett, S. Hoshek and I.M. Sacker. 1967. Effect of starvation on hyaluronic acid and extractable protein in skin of mice. Am. J. Physiol. 212: 773-776.

Sorvachev, K.F. 1957. Changes in protein of carp blood during hibernation. Biokhimiy 22: 872-878.

Sutherland, W., C.P. Cori, R. Haynas and N.S. Clean. 1949. Adipose tissue cellularity and lipid metabolism in 2 lines of mice selected for high and low resistance to starvation, Jpn. J. Zootech Sci. 51(4): 293-300.

Thomas, M.L.H. and H.R. McCrimmon. 1964. Variability in paper electrophoretic patterns of the serum of landlocked Sea Lamprey, Petromyzon marinus Linnaeus. J. fish. Res. Bo. Can. 21(2): 239-246.

Tripathi, G. and P. Verma .2003. Starvation-induced impairment of metabolism in a freshwater catfish, $Z$. Naturforsch. 58c: 446-451. 